\title{
Assessment and Research of River Restoration Processes in Regulated Streams of Southeastern Lithuania
}

\author{
Oksana Survilè, Valentinas Šaulys, Lina Bagdžiūnaitė-Litvinaitiené*, \\ Rasa Stankevičienė, Andrius Litvinaitis, Mindaugas Stankevičius
}

\author{
Department of Water Engineering, Vilnius Gediminas Technical University, \\ Saulètekio al. 11, LT-10223, Vilnius, Lithuania
}

Received: 15 December 2015

Accepted: 6 February 2016

\begin{abstract}
The article deals with the auto-naturalization problems of regulated streams in Lithuania. Research on such streams overgrown with woody vegetation was conducted in the Neris River basin in the Baltic Highlands. We chose to investigate the most urbanized rough terrain area of southeastern Lithuania. The regulated streams found in this area include stretches with a relatively high reserve of hydraulic conductivity. Therefore, with reference to the Water Framework Directive for improving the ecological situation, we assessed the possibilities of promoting the naturalization process.

The average density of woody vegetation on the investigated slopes of regulated streams is $T=1.26 \pm 0.20$ items $\mathrm{m}^{-2}$. The slopes with northeastern exposure point to the average density of woody vegetation counting $T_{N E}=0.91$ items $\mathrm{m}^{-2}$, which is 2.42 times more than that observed on the slopes with eastern exposure and 2.30 times more than those with southern exposure $\left(T_{S}=0.39\right.$ items $\left.\mathrm{m}^{-2}\right)$. Under the presence of the recent density of woody vegetation, hydraulic measurements established Manning's roughness coefficient that varied from 0.030 to 0.094 . The conducted simulation indicates that the studied stretches of regulated streams lose a margin of hydraulic conductivity when Manning's roughness coefficient reaches a threshold of $0.060-0.080$. Planning the naturalization of regulated streams is first offered in the stretches of higher slopes $\left(S_{0}>0.003\right)$, where the maintenance of the adequate roughness of the bed may assist in designing the overgrowth of both slopes with woody vegetation.
\end{abstract}

Keywords: regulated streams, river restoration, hydraulic roughness, woody vegetation

\section{Introduction}

A number of projects looking at changes in the natural flow of water have been carried out in Lithuania

*e-mail: andrius.litvinaitis@vgtu.lt and worldwide. Due to human economic activities, the morphometric parameters of the riverbed have been extensively transformed. Natural riverbeds have been straightened and deepened, artificially forming slopes and erecting dams. The works done have changed not only the morphometric parameters of rivers, but also water flow has been generated, the processes of erosion have become 
more intensive, and vegetation growing on the slopes of the bed has varied [1].

Recently, a revision of surveillance technologies for regulating streams focused on drainage has become a burning issue in European countries and globally, and new methods for harmonizing agricultural productivity or at least partially restoring the lost ecological balance have been applied. Therefore, a number of economically developed countries have accomplished mechanical naturalization, including regulated rivers having excavated meanders and backwaters not suitable to the bed, and pools and shoals forming with coastal areas being greeted with trees and shrubs [2-3]. The beds of regulated streams face spontaneous deformation processes [4-5].

A protection zone for river/stream banks is a crucial element of an ecological network. The significance and impact of the protection zone on the quality of water has been described by Lithuanian and foreign scientists [6$10]$. Woody and grassy vegetation growing in protection zones for river/stream banks helps prevent contamination by nutrients and pesticides, partially suppresses dirt brought by flooding, protects against erosion, and reduces the intensive prosperity of water crops, thus producing a shading effect and creating new land aquatic ecosystems.

Works by Lamsodis et al. [11] and Thomas et al. [12] widely described the composition of the species of woody vegetation. Lamsodis [13] investigated the distribution of woody vegetation according to frequency and density in reclamation trenches. They discovered that the density of shrubs rather than that of trees in the Nevèžis plain is always higher. Although absolute differences are constantly decreasing at the distance from the forest, in relative terms the greatest variations are detected in ditches, which means that shrubs - particularly the willows of Salix species - make up the major part (54$88 \%$ ) of woody vegetation in the ditches investigated by R. Lamsodis.

Woody vegetation, trees, and shrubs growing on the regulated slopes of streams have an impact on the morphometric parameters of the stream [14]. It has also been found that the cross-section of the streams overgrown with woody vegetation takes more space than that of the streams having no woody vegetation [15]. Thus, the streams with no overgrown woody vegetation and steeper slopes have higher probability for tides and destroying slopes. Bertoldi et al. [16] agree that ensuring the stability of stream slopes and an increase in hydraulic conductivity are the two main factors that help woody vegetation make an impact on the morphometric parameters of the stream.

The growth of grassy and woody vegetation in drainage channels and regulated streambeds is one of the natural processes most radically affecting their condition. The conducted research has disclosed that grasses growing in regulated streambeds increase the roughness of their surface, reduce the velocity of water, promote sediment deposition, and increase the risk of flooding [17-19].

Our paper is aimed at investigating the quantitative and qualitative peculiarities of regulated streams overgrown with spontaneous woody vegetation under naturalization processes and using hydraulic modelling to assess variations in the functionality of regulated streams (hydraulic roughness of slopes, hydraulic conductivity) and the possibilities of planning the naturalization processes of regulated streams in the region of the highlands of southeastern Lithuania.

\section{Materials and Methods}

\section{Study Area}

We chose to research 17 regulated streams in Lithuania: Vaišvilè (1), Dūkšta (2), Vilnoja (3), Gnesvianka (4), Ž-2 (5), Girija (6), Žalesa (7), Ž-3 (8), R-55 (9), Riešè (10), G-1 (11), Nemėža (12), Mažasis (13), Rudamina (14), N-2 (15), Asdrè (16), and Bezdonė (17). Research locations are from $24^{\circ} 55^{\prime}$ to $25^{\circ} 35^{\prime}$ east longitude and from $54^{\circ} 33^{\prime}$, to $54^{\circ} 53^{\prime}$ north latitude (Fig. 1).

More detailed study on the roughness coefficient involved 4 regulated streams. Single cases of investigation into the roughness coefficient were conducted in the stretches that were extremely overgrown with woody and grassy vegetation.

Neméža stream (12) is a tributary of the Rudamina River. The length of the stream is $10.3 \mathrm{~km}$ with an adjusted catchment area of $42.8 \mathrm{~km}^{2}$ [20]. For research purposes, we selected the middle part of the stream (from pickets 22 to 29). We found a $4.5 \%$ slope in the upper part of the investigated stretch from pickets 27 to 29 , while that in the lower part (from 22 to 27 ) reaches only $0.6 \%$. According to data provided by the Lithuanian Water Management Institute, the expected lowest discharge (90\%) at the beginning of the researched stretch takes place in summer and reaches $0.365 \mathrm{~m}^{3} / \mathrm{s}$, whereas the expected highest discharge $(10 \%)$ at the end of the researched stretch can be observed in the spring period and makes $5.50 \mathrm{~m}^{3} / \mathrm{s}$.

Girija Stream (6) is a tributary of the Žalesa River. A $4 \mathrm{~km}$ stretch from the confluence of the stream is regulated. The stream is $5.5 \mathrm{~km}$ in length with an adjusted

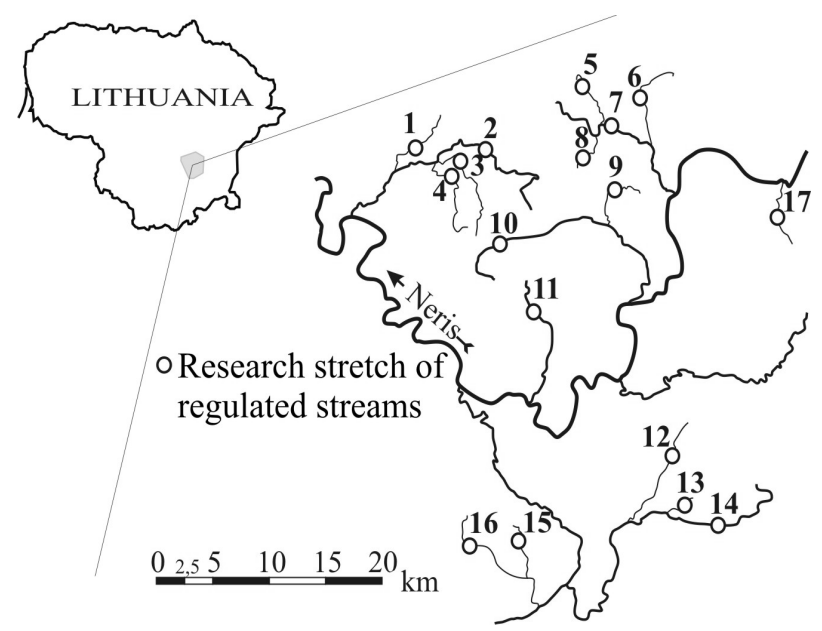

Fig. 1. Location of the study area. 
catchment area of $35.2 \mathrm{~km}^{2}$ [20]. We chose to look at the middle part of the stream (from pickets 3 to 11). A slope in the investigated stretch of the stream varies from 2.5 to $3 \%$ in different profiles.

The Žalesa (7) is a tributary of the Neris River. A $7.6 \mathrm{~km}$ stretch from the springhead is regulated. The length of the river is $18.8 \mathrm{~km}$ with a catchment area of $97.1 \mathrm{~km}^{2}$. Again, we selected the middle part of the stream (from pickets 8 to 13). A slope in the investigated stretch of the stream varies from 0.3 to $2.5 \%$ in different profiles.

Stream Ž-2 (5) is completely regulated. The length of the stream is $4.5 \mathrm{~km}$ and the catchment area is $10.5 \mathrm{~km}^{2}$ [20]. We selected the middle part of the stream (from pickets 2 to 17). A slope in the investigated stretch of the stream varies from 0.5 to $8.0 \%$ in different profiles.

\section{Investigation Methods}

To establish the coefficients of the hydraulic roughness of regulated streams, we applied methodology based on the hydraulic calculations of deformed ditches overgrown with shrubs and trees as worked out by the Water Management Institute of the Lithuanian University of Agriculture [21]. To discover roughness coefficient $n$, the following parameters of the regulated stream were measured: the width of ditch bottom $b(\mathrm{~m})$, slope coefficient $\mathrm{m}$, the width of the shrubby section of the left and right slopes $b_{\mathrm{KrD}}, b_{\mathrm{KrK}}(\mathrm{m})$, the width of the lower and upper sections not overgrown with vegetation on the left and right slopes, the density of woody vegetation $T$ (items $\mathrm{m}^{-2}$ : the quantity of stems per $1 \mathrm{~m}^{2}$ of the slope area), the number of trunks in the linear metre of the tree section on the left and right slopes, and the incidence of woody vegetation $D(\%$ : the ratio of slope sections where a species was identified with the number of all investigated sections). We measured the height of sediments in bed $h(\mathrm{~cm})$ and bed-load grain size $d_{90}(\mathrm{~mm})$ in order to evaluate the dependency of sediment accumulation on the streambed slope. Data on the spread of woody vegetation in regulated streambeds was processed by applying the methods of mathematical statistics.

The force of hydraulic resistance $\Delta T$ affecting the stem cell of a sapling of $\Delta H$ in height and $d$ in diameter can be expressed as follows:

$$
\Delta T=\rho C_{f} K_{l} \Delta H d \frac{v^{2}}{2 g}
$$

...where $\rho$ is fluid density, $C_{f}$ is the coefficient evaluating the form of the trunk, $K_{l}$ is the coefficient evaluating the density of the trunk, $\Delta H$ is the height of the stem cell, $d$ is the diameter of the sapling stem, and $v$ is flow velocity.

To assess the roughness coefficient (the width of the slope sections overgrown with coarse-grassy vegetation) we measured the height of grass and the bottom overgrown with grassy vegetation. The slope of the calculated stretch was received with reference to data provided by the Lithuanian Water Management Institute.
The assessment of the impact of woody vegetation on the hydraulic conductivity of the stream assisted in setting water levels for simulating regulated streams in which the HEC-RAS program was chosen. Software (RASRiver Analysis System) developed by the Hydrologic Engineering Centre (HEC) focuses on making onedimensional calculations of a steady and unsteady flow or sediment [22]. The HEC-RAS model solves full 1D St. Venant equations for an unsteady open channel flow:

$$
\begin{gathered}
\frac{\partial \mathrm{A}}{\partial \mathrm{t}}+\frac{\partial \varphi Q}{\partial x_{c}}+\frac{\partial[(1-\varphi)] Q}{\partial x_{f}}=0 \\
\frac{\partial Q}{\partial \mathrm{t}}+\frac{\partial}{\partial \mathrm{x}_{c}}\left(\frac{\varphi^{2} Q^{2}}{A_{c}}\right)+\frac{\partial}{\partial \mathrm{x}_{f}}\left(\frac{\left(1-\varphi^{2}\right) Q^{2}}{A_{f}}\right) \\
+g A_{c}\left(\frac{\partial \mathrm{z}}{\partial \mathrm{x}_{c}}+S_{c}\right)+g A_{f}\left(\frac{\partial \mathrm{z}}{\partial \mathrm{x}_{f}}+S_{f}\right)=0 \\
\varphi=\frac{K_{c}}{K_{c}+K_{f}}, \quad K=\frac{A^{5 / 3}}{n P^{2 / 3}} \\
S_{c}=\frac{\varphi^{2} Q^{2} n_{c}^{2}}{R_{c}^{4 / 3} A_{c}^{2}}, \quad S_{f}=\frac{(1-\varphi)^{2} Q^{2} n_{f}^{2}}{R_{f}^{4 / 3} A_{f}^{2}}
\end{gathered}
$$

...where $Q$ is the total flow down the reach, $A\left(A_{c}, A_{f}\right)$ is the cross-sectional area of the flow (in the channel, floodplain), $x_{c}$ and $x_{f}$ are distances along the channel and floodplain (these may differ between cross-sections to allow for channel sinuosity), $P$ is the wetted perimeter, $R$ is the hydraulic radius $(A / P), n$ is Manning's roughness coefficient, and $S$ is friction slope. $\varphi$ determines how flow is partitioned between the floodplain and channel, according to conveyances $K_{c}$ and $K_{f}$. These equations are discretized using the finite difference method and solved using a four-point implicit (box) method [23].

The thickness of the accumulated sediment layer was measured in the stream stretches having different slopes $\left(S_{0}\right)$, and the samples of bed-load sediment were taken for granulometric analysis.

Water overflow rate was established in the investigated stretches of the stream. It can be accepted as positive ( $h v \leq$ $h g$ ) when the level of water in the investigated regulated streambed (hv) is lower than or equal to the depth of the regulated stream $(h g)$ (water doesn't overflow) and can be referred to as negative when the level of water in the streambed $(h v)$ is higher than the depth of the regulated stream $(h g)$ (water overflows from the streambed).

\section{Results and Discussion}

The conducted research on regulated streams in Lithuania has revealed that the slopes of beds are covered by different trees and shrubs. In total, 33 species of woody 
vegetation have been found, including 16 species of trees and 17 species of shrubs. The general frequency of all species of woody vegetation on the slopes of regulated streams reaches $71 \%$ (shrub prevalence is $59 \%$ and that of trees is 49\%).

To evaluate the multiplicity of vegetation we calculated the general density of woody vegetation $T$. The general number of stems is $T=1.26 \pm 0.20$ items $\mathrm{m}^{-2}$ (variation coefficient $C_{V}=2.14$, the standard error of the mean $\mathrm{S}_{\mathrm{X}}= \pm 0.06$, the average error under the reliance of $95 \%$, $\mathrm{S}_{\mathrm{X} 0.05}= \pm 0.12$ items m$^{-2}$ ), that of trees is $T_{M}=0.23 \pm 0.04$ items $\mathrm{m}^{-2}$, and that of shrubs is $T_{K}=1.04 \pm 0.20$ items $\mathrm{m}^{-2}$.

The evaluation of overgrown stretches only demonstrates that the density of the woody vegetation of different regulated streams also varies and depends on a number of natural (distance to the forest, slope exposition) and anthropogenic (agricultural land) factors, whereas woody vegetation growing on the slopes of regulated streams has an impact on the morphological parameters of the riverbed [15]. An increased density of woody vegetation was observed in the regulated streams crossing a non-urbanized territory thickly overgrown with woody vegetation (Fig. 2). The density of the woody vegetation of regulated streams close to settlements and cultivated fields is much lower (Rudamina, Mažasis, Riešè). The density of woody vegetation has also been noticed to be low in the regulated streams crossing the forest (Bezdonè), as their slopes are overgrown with trees.

At the distance from the forest, the general density of woody vegetation as well as - separately - that of trees and shrubs decreases. As regards the forest and the outskirts of the forest, the decreased general density of woody vegetation, at a distance of 100-300 $\mathrm{m}$ from the forest, was noticed, which is determined by the increased density of the trees rather than by that of shrubs found in the forest and the outskirts of the forest. The diameter of tree stems is larger and, therefore, general density is lower. A heavy dependence of the density of general woody vegetation on the distance of the places of findings to the forest was received ( $r=0.70-0.90)$.

The established distribution of woody vegetation may also vary depending on the exposure of the slope. The average of the density of woody vegetation on

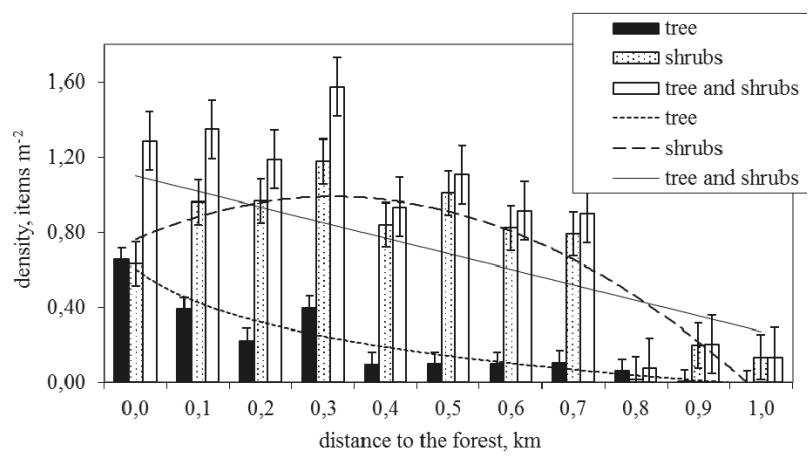

Fig. 2. The dependence of the density of woody vegetation on the distance of the stream to the forest. slopes with northeastern exposure $\left(T_{N E}=0.905 \pm 0.304\right.$ items $\mathrm{m}^{-2}$ ) is 2.42 times more than that of eastern slopes and 2.30 more than southern ones $\left(T_{S}=0.393 \pm 0.118\right.$ items $\mathrm{m}^{-2}$ ). A greater amount of vegetation on the slopes of northern, northeastern, southwestern, and northwestern slopes shows that conditions for the growth of wooden vegetation are much better in such places. Western and southwestern winds prevail in Lithuania. Thus, the wind most frequently blows to the slopes with western and southwestern exposure. These slopes, due to more frequent rains blown by the previously mentioned winds, receive more rainfall, whereas northern- and northeasternexposed slopes are less warmed and therefore dry out or burn. In order to evaluate the main differences between the densities of woody vegetation on the slopes with different exposures we conducted dispersive analysis. This examination disclosed that the averages of density on the slopes of different exposures are essentially the same (Fig. 3).

Research on the distribution of woody vegetation overgrown on the slopes of regulated streams reveals variations in the slopes of regulated streams. The highest density and frequency of woody vegetation were established in the middle part of the slope. The density of woody vegetation was measured in the middle part of the slope and makes $T=2.00 \pm 0.48$ items $\mathrm{m}^{-2}$, whereas that at the base is lower and reaches $T=1.53 \pm 0.27 \mathrm{items}^{-2}$. The lowest density and frequency of woody vegetation can be observed in the upper part of the slope and is equal to $T=0.55 \pm 0.11$ items $\mathrm{m}^{-2}$.

A comparison of the density of trees and shrubs points to a smaller amount of trees rather than shrubs, the highest density of which was measured in the middle part of the slope; however, the difference $-0.14 \pm 0.04,0.32 \pm 0.06$, $0.24 \pm 0.05$ items $\mathrm{m}^{-2}-$ is not large.

Tymiński and Kałuża [24] suggest that the growth of grassy and woody vegetation in riverbeds is one of the processes taking place in nature and significantly affects their condition. The growth of grasses has been found to decrease erosion risk in the beds of regulated streams but, according to our research, increases the roughness of their surface, reduces water flow rates, stimulates

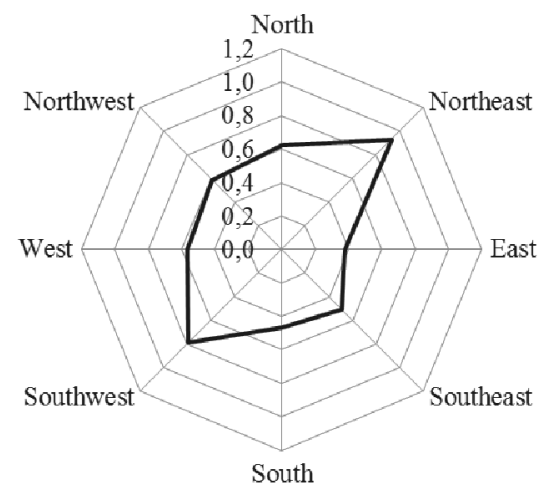

Fig. 3. The density of woody vegetation on slopes with different exposures. 
sediment deposition, and raises the risk of flooding. Flood risk depends on the density of vegetation, the slope of the riverbed, and the species composition of woody vegetation. After a flood, some types of woody vegetation (such as willows and alders) are restored to their original condition, whereas other species are destroyed.

The conducted natural research has disclosed that the density of woody vegetation in the investigated Neméža Stream varies from 0.01 to 0.68 items $\mathrm{m}^{-2}$, in the $\check{Z}-2$ Stream from 0.17 to 5.42 items $\mathrm{m}^{-2}$, in the Žalesa River from 0 to 2.14 items $\mathrm{m}^{-2}$, and in Girija Stream from 0 to 3.33 items $\mathrm{m}^{-2}$. The interdependence between the density of woody vegetation and the value of Manning's roughness coefficient has been noticed. Under the density of woody vegetation of $0,01-0.16$ items $/ \mathrm{m}^{2}$ in the Neméža stream, Manning's roughness coefficient has amounted to 0,035 . An increase in the density of woody vegetation on the slopes resulted in a Manning's roughness coefficient of 0.040 .

As for $\check{Z}-2$, under the density of woody vegetation of 0.17-1.62 items $\mathrm{m}^{-2}$, Manning's roughness coefficient reached 0.040 . When the density of woody vegetation varies from 2.30 to 5.42 items $\mathrm{m}^{-2}$, Manning's increases to 0.050 . The dependence of the hydraulic roughness coefficient on woody vegetation has also been assessed in several stretches of other regulated streams of Vilnoja and Vaišvilè. Under the density of 1.66 items $\mathrm{m}^{-2}$ of woody vegetation in the regulated Vilnoja stream, Manning's $n$ amounts to 0.057 [25]. Besides, Neméža and Ž-2 streams overgrown with coarse-grassy vegetation have been regulated, thus assessing its impact on the roughness coefficient.

The slopes of Vaišvilè stream overgrown with reeds has resulted in a Manning's roughness coefficient $n$ of 0.094 , which is the highest value received within experimental research.

To evaluate the dependence of water levels on the hydraulic roughness coefficient, we simulated water levels using HEC-RAS. RAS-River Analysis System software created by the Hydrologic Engineering Centre (HEC) focuses on making one-dimensional calculations of a steady and unsteady flow or sediment [22]. We performed

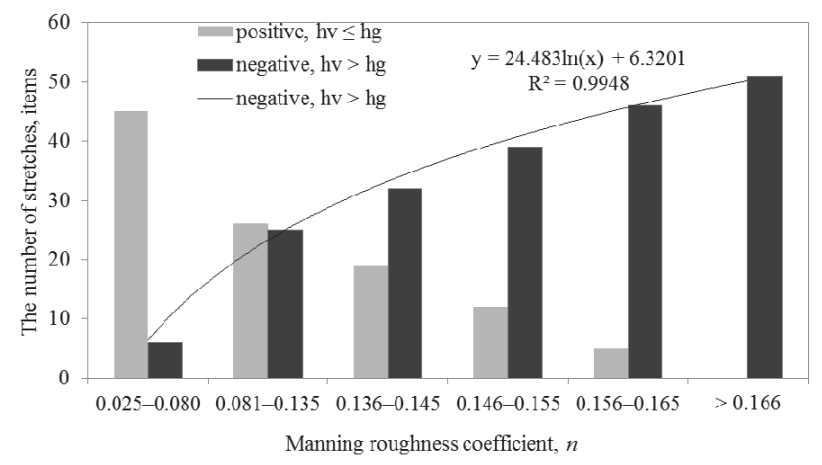

Fig. 4. The dependence of the overflow of water indexes on hydraulic roughness coefficient $n$ under the maximum flow rate of $10 \%$ probability at the time of spring flooding. simulations under the current set hydraulic roughness coefficients and maximum flow rates.

Our hydraulic simulations of regulated streambeds revealed that, under the present roughness of the Neméža (from 0.030 to 0.045 ), Ž-2 (from 0.030 to 0.053 ), and Girija (from 0.036 to 0.067 ) streams, and the Žalesa River (from 0.033 to 0.042 ), spring flood water is within the boundaries of the stream and therefore does not overflow. In all cases, water level $h v$ is lower than streambed $h g$.

An increase in the hydraulic roughness coefficient of up to $0.136-0.145$ causes the overflow of water in 10 stretches of the Neméža, in 12 stretches of the $\check{Z}-2$, in four stretches of the Žalesa, and in six stretches of the Girija under Manning's roughness coefficient of 0.170. A negative index of the overflow of water is received in all investigated stretches of the streams (Fig. 4).

The indexes of the overflow of water - under the maximum flow rate of $10 \%$ probability at the time of the spring flood and considering an increase in the values of hydraulic roughness coefficient $n$ - vary significantly. The number of stretches where water overflows from the streambed $(h v>h g)$ substantially grows along with the values of the roughness coefficient.

According to Rimkus [21], in order to avoid the aboveintroduced situation, woody vegetation should be thinned out or other methods for decreasing streambed roughness should be applied. For example, if the slopes of the streambed overgrew with woody or grassy vegetation and Manning's hydraulic roughness coefficient exceeded the value of $0.060-0.080$, complying with requirements for the hydraulic conductivity of streambeds, a section free of trees should be formed at the bottom of the slope, or trees should be thinned out along the whole slope, or vegetation should be completely removed from one of the slopes, thus decreasing the roughness coefficient of the streambed within acceptable limits (0.060). Under cutting down trees or shrubs, leaving the southern slope overgrown is recommended $[11,21]$ because, as mentioned above, wooden vegetation growing on the southern slope will produce stronger shadows into the streambed as well as inhibit the scale of an overgrowth of the northern slope and the bottom with grassy and water vegetation, thus decreasing streambed silting.

In the case of the stream overgrown with coarsegrassy vegetation (roughness may reach 0.290 an even more), slopes could be mown so that the maximum flow of $10 \%$ probability should be within the boundaries of the streambed. Mowing frequency should be in the range so that coarse-grassy vegetation should not prevail (Manning's roughness coefficient should not exceed 0.080).

The Neméža stream flows from northeast to southwest, and thus woody vegetation should be left on the southeastern slope of the regulated stream. The $\check{Z}-2$ stream flows from west to east, and therefore wooden vegetation should be left on the southern slope of the stream. At the moment, the roughness coefficients of the streams have not yet reached a critical threshold (0.060$0.080)$. The index of the overgrowth of water is positive 
along all stretches of all investigated streams, and hence the removal of saplings and shrubs is not required. The regulated streams of Girija and Žalesa flow at the outskirts of the forest with no cultivated fields around, and therefore the removal of woody or grassy vegetation does not make any sense. Regarding these stretches, a large increase in the density of wooden vegetation along with hydraulic roughness is fully acceptable. However, the cycle of the regulated stream becomes similar to that of natural streams. Due to the fact that these streams run in poorly urbanized areas, restoring the natural cycle of these streams is much easier and does not require huge financial resources, which is confirmed by works performed in urbanized areas by Bernhardt and Palmer [2].

An important point of restoring the disturbed hydrological and environmental balance of regulated streams is fulfilling the function of draining streams to avoid an increase in maintenance costs. Depending on the square of the river basin, land use, topographicalgeographical conditions, and surface runoff, different contents of outwash enter regulated streams [26]. The transfer of outwash in regulated streams is introduced as one of the most important naturalization processes [27]. However, discharge forming the bed in the investigated streams is only recorded at the time of spring flooding. From this point of view, the stretches of regulated streams with a small slope seem to be very dangerous. The research

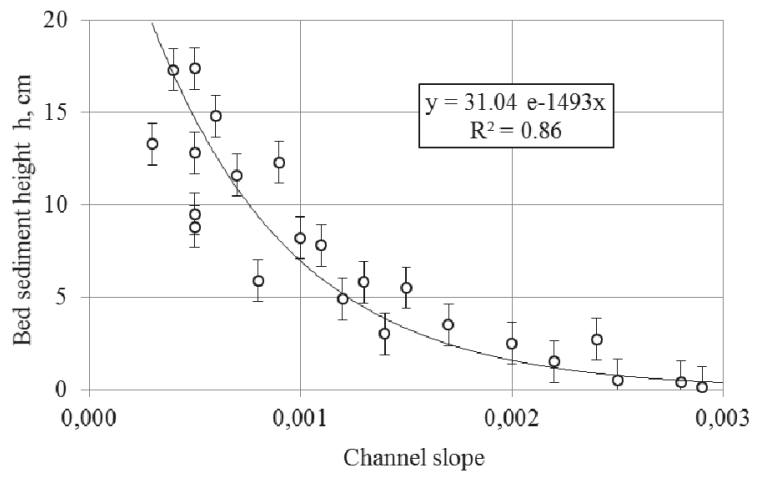

Fig. 5. The dynamics of the streambed slope and accumulated sediments.

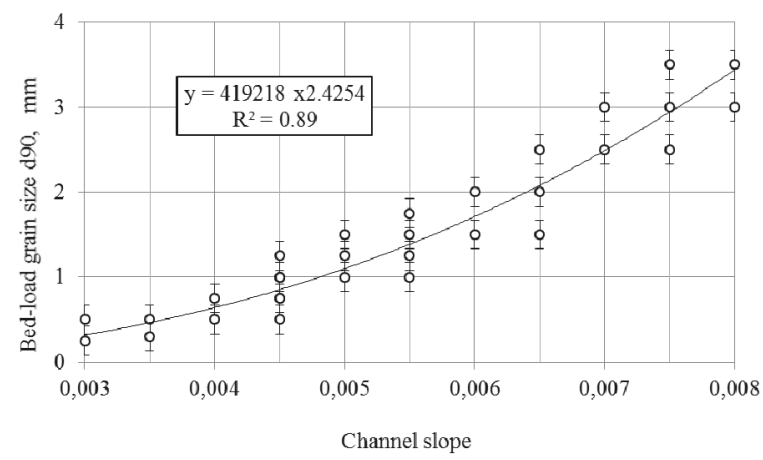

Fig. 6. Variations in the size of the streambed slope and bed-load sediments. carried out demonstrates that, under small slopes, sediment accumulation can be observed in regulated streambeds (Fig. 5). The above-discussed sediment accumulation process is usually monitored under streambed slopes of less than $3.0 \%$.

An increase in the streambed slope (Fig. 6) along with flow velocity allows us to observe the transfer of the sediment falling into the riverbed in a downstream direction. The amount, content, and composition of the transferred sediment depends on a number of natural factors such as precipitation, pool-prevailing sediments, and their conductivity, dominant vegetation, etc.

Either with surface runoff or in the course of the erosion of riverbed slopes, sediment entering the bed under slopes higher than $3.0 \%$ - are transferred along the bed, and silting does not take place. This form of transfer depends on the terrain, geological basin architecture, water and ice events in the pool, hanging and bed-load sediment in the catchment, the methods they access the bed, coarse sediment, etc. Nevertheless, planning the naturalization of regulated streams is a crucial factor that allows maintaining the draining function of streams. Considering the stretches having a higher slope and maintaining certain roughness of the bed, the overgrowth of both slopes with woody vegetation can be planned. Meanwhile, in the stretches having a lower slope $\left(S_{0}<0.003\right)$, necessary sediment removal works must be figured out and therefore, in this case, it seems to be optimal to plan the overgrowth of a single slope of the bed with woody vegetation.

\section{Conclusions}

The diversity of the species of woody vegetation on the slopes of regulated streams depends on the position of streams in the territory (forest, outskirts of the forest, agricultural land). A heavy dependence of the density of general woody vegetation on the distance of the places of findings to the forest ( $r=0.70-0.90)$ has been received.

Our research has disclosed the highest average $\left(T_{N E}=0.905 \pm 0.304\right.$ items $\left.\mathrm{m}^{-2}\right)$ of the density of woody vegetation on northeasterly exposed slopes (2.42 times higher than those of eastern and 2.30 times higher than those of southern $\left(T_{S}=0.393 \pm 0.118\right.$ items $\left.\mathrm{m}^{-2}\right)$ exposure. However, our dispersive data analysis has revealed that the averages of density on the slopes of different exposure, under $95 \%$ reliability, mainly remain the same.

With reference to the morphometric parameters of the beds of regulated streams and the distribution and density of woody vegetation in the transversal profile of the bed, the established Manning's roughness coefficient varies from 0.030 to 0.094 . Thus, it can be stated that regulated streams in southeastern Lithuania involve stretches where the margin of hydraulic conductivity at the time of flooding decreases up to the limits of an overflow to the valley.

The performed simulation has demonstrated that the margin of hydraulic conductivity in the investigated stretches of regulated streams is lost when Manning's roughness coefficient is within the limits of $0.060-0.080$. 
It can be maintained that, in case the slopes of the streambed overgrew with woody and grassy vegetation and Manning's roughness coefficient should exceed $0.060-0.080$, it might be necessary to reduce streambed roughness up to acceptable limits, thus ensuring the hydraulic conductivity of beds.

For planning the naturalization of regulated streams, we first suggest focusing on the stretches having higher slopes $\left(S_{0}>0.003\right)$ where, under the maintenance of a certain roughness of the bed, the overgrowth of both slopes with woody vegetation needs to be designed.

\section{References}

1. GREGORY K. J. The human role in changing river channels. Geomorphology. 79, 172, 2006.

2. BERNHARDT E.S., PALMER M.A. Restoring streams in an urbanizing world. Freshwater Biology. 52 (4), 738, 2007.

3. BOUDELL J.A., DIXON M.D., ROOD S.B., STROMBERG J.C. Restoring functional riparian ecosystems: concepts and applications. Ecohydrology. 8 (5), 747, 2015.

4. STROBL K., WURFER A.L., KOLLMANN J. Ecological assessment of different riverbank revitalization measures to restore riparian vegetation in highly modified river. Tuexenia. 35, 177, 2015.

5. BĄK Ł., MICHALIK A., TEKIELAK T. Appraise of consequences of erosive processes occurring in the Skawa river sector. Environment Protection Engineering. 31 (1), 83, 2011.

6. BARITEAU L., BOUCHARD D., GAHNON G., LEVASSEUR M., LAPOINTE S., BERUBE M. A riverbank erosion control method with environmental value. Ecological Engineering. 58, 384, 2013.

7. MC CONIGLEY C., LALLY H., O'CALLAGHAN M., O' DEA P., LITTLE D., KELLY-QUINN M. The vegetation communities of unmanaged aquatic buffer zones within conifer plantations in Ireland. Forest Ecology and Management. 353, 59, 2015.

8. KIEDRZYŃSKI M., KIEDRZYŃSKA E., WITOSŁAWSKI P., URBANIAK M., KUROWSKI J.K. Historical Land Use Actual Vegetation, and the Hemeroby Levels in Ecological Evaluation of an Urban River Valley in Perspective of Its Plan. Polish Journal of Environmental Studies. 23 (1), 109, 2014.

9. SAHU M., GU R.R. Modeling the effects of riparian buffer zone and contour strips on stream water quality. Ecological Engineering. 35 (8), 1167, 2009.

10. HE J., AI J., ZHU X., SUN X. Ecological Compensation Standarts of Wetland Restoration Projects. Polish Journal of Environmental Studies. 24 (6), 2421, 2015.

11. LAMSODIS R., MORKŪNAS V., POŠKUS V., POVILAITIS A. Ecological approach to management of open drains. Irrigation and drainage. 55 (5), 479, 2006.

12. THOMAS L.K., MOSNER E., LEYER I. River dynamics and invasion: distribution patterns of native and invasive woody vegetation at the Rio Negro, Argentina. Riparian Ecology and Conservation. 2 (1), 45, 2015.

13. LAMSODIS R. Botanical structure and spread of woody vegetation in drainage channels. Water Management Engineering. 20, 31, 2002 [In Lithuanian].

14. EATON B.C., MILLAR R.G. Optimal alluvial channel width under a bank stability constraint. Geomorphology. 62 (1), 35, 2004.

15. HESSION W.C., PIZZUTO J.E., JOHNSON T.E., HORWITZ R.J. Influence of bank vegetation on channel morphology in rural and urban watersheds. Geology. 31 (2), $147,2003$.

16. BERTOLDI W., WELBER M., GURNELL A.M., MAO L., COMITI F., TAL M. Physical modelling of the combined effect of vegetation and wood on river morphology. Geomorphology. 246, 178, 2015.

17. SHUCKSMITH J.D., BOXALL J.B., GUYMER I. Bulk Flow Resistance in Vegetated Channels: Analysis of Momentum Balance Approaches Based on Data Obtained in Aging Live Vegetation. Journal of Hydraulic Engineering. 137 (12), 1624, 2011.

18. LI Y., DU W., YU Z., TANG CH., WANG Y., ANIM D. O., NI L., LAU J., CHEW S. A., ACHARYA K. Impact of flexible emergent vegetation on the flow turbulence and kinetic energy characteristics in a flume experiment. Journal of Hydro-environment Research. 9, 354, 2015.

19. MAGNUSZEWSKI A. Influence on Flood Safety of Channel Processes and Vegetation in the River Vistula Valley in Warsaw. Stochastic Flood Forecasting System, GeoPlanet: Earth and Planetary Sciences.129, 2015.

20. GAILIUŠIS B., JABLONSKIS J., KOVALENKOVIENE் M. Lithuanian rivers: Hydrography and runoff. Kaunas: LEI, 2001 [In Lithuanian].

21. RIMKUS A., VAIKASAS S. The hydraulic calculations for naturalized channels. Journal of Water and Land Development. 3, 101, 1999.

22. USAGE (US Army Corps of Engineers), HEC-RAS river analysis system user's manual, Gary W. Brunner, Hydrologic Engineering Center, 2010.

23. HORRITT M.S., BATES P.D. Evualuation of $1 D$ and 2D numerical models for predicting river flood inundation. Journal of Hydrology. 268, 87, 2002.

24. TYMIŃSKI T., KAŁUŻA T. Investigation of Mechanical Properties and Flow Resistance of Flexible Riverbank Vegetation. Polish Journal of Environmental Studies. 21 (1), 201, 2012.

25. BARVIDIENĖ O., ŠAULYS V. Modeling of hydraulic conductivity in the regulated streams of southeast Lithuania., In. Proc. $8^{\text {th }}$ Conference on Environmental Engineering; 525, Lithuania, Vilnius, 2011.

26. ZHANG X., CAO W., GUO Q., WU S. Effects of landuse change on surface runoff and sediment yield at different watershed scales on the Loess Plateau. International Journal of Sediment Research. 25 (3), 283, 2010.

27. MIWA H., PARKER G. Numerical simulation of lowflow channel evolution due to sediment augmentation. International Journal of Sediment Research. 27 (3), 351, 2012. 